\title{
Astmameðferð á krepputímum
}

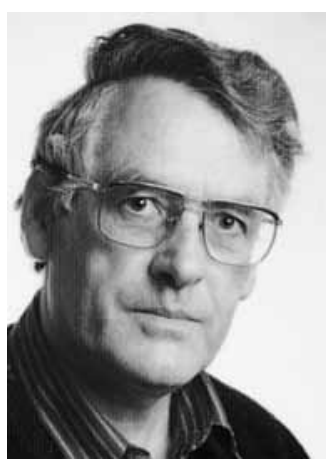

Davíð Gíslason

davidg@landspitali.is

Höfundur er sérfræðingur í lyflækningum og ofnæmissjúkdómum, Landspítala Fossvogi og klínískur dósent við Háskóla Íslands.

Asthma treatment in economic crisis

Gislason D, Specialist in Internal Medicine and Allergology, Dept. of Allergy, Respiratory Medicine and Sleep, Landspitali University Hospital, 108 Reykjavik Iceland
Pegar kreppir að í pjóðfélaginu, eins og nú gerir, er leitað allra leiða til að draga úr útgjöldum ríkissjóðs. Við sem vinnum í heilbrigðiskerfinu finnum ápreifanlega fyrir pví.

Í sambandi við útgjöld til heilbrigðismála hefur lyfjakostnaður lengi verið í brennidepli. Í peirri umræðu vill oft gleymast mikilvægi lyfja í nútíma læknisfræði. Sú var tíðin að astmasjúklingar voru tíðir gestir á bráđamóttökum og legudeildum spítalanna. Petta hefur breyst með tilkomu nýrra astmalyfja pótt orðið hafi preföldun á algengi astma hjá ungu fólki hér á landi eftir 1990 (óbirtar heimildir). Finnar voru með sérstakt átaksverkefni varðandi astma á árnum 1994-2004. ${ }^{1}$ Frá 1980-1999 varð nærri fjórföldun á algengi astma par í landi, en prátt fyrir pað fækkaði innlögnum á sjúkrahús um 36\% og dauðsföllum af völdum astma fækkaði enn meira.

Kostnaður vegna astma var kannaður í 11 Evrópulöndum árin 2000-2002. Hann var eðlilega minnstur hjá peim sem hvorki misstu úr vinnu eða lentu á sjúkrahúsi, en átta sinnum meiri hjá peim sem misstu úr vinnu og purftu að leggjast á sjúkrahús. ${ }^{2}$ Langmestur kostnaður var fólginn í vinnutapi. Virkari lyf við astma hafa sparað miklar fjárhæðir fyrir samfélagið og bætt lífsgæði fjölda fólks.

Kostnaður ríkissjóðs vegna astmalyfja (R03) var 841 milljón króna árið 2008 og hafði pá aukist um $45 \%$ á síðustu sex árum (Sjúkratryggingar Íslands www.sjukra.is). Pá parf að taka með í reikninginn að langvinn lungnateppa (LLT) er meðhöndluð með astmalyfjum, en $9 \%$ Íslendinga fjörutíu ára og eldri eru með pennan sjúkdóm á GOLD stigi 2-4. ${ }^{3}$

Pegar notkun astmalyfja fyrir árið 2007 er skoðuð sést að fjórðungur drengja og fimmtungur stúlkna fengu astmalyf á fyrstu fjórum æviárunum. Má ætla að parna sé um töluverða ofnotkun að ræða miðað við ríkjandi hefð um meðferð. Af sjúklingum með langvinna lungnateppu nota $20 \%$ berkjuvíkkandi lyf og 26\% innöndunarstera á GOLD stigi tvö. Á GOLD stigum prjú og fjögur nota 50\% berkjuvíkkandi lyf og 36\% innöndunarstera. Ætla má að á vægara stiginu séu óparflega margir á öflugri meðferð en einhverjir vanmeðhöndlaðir á stigi prjú og fjögur. Við samanburð á meðferð á astma í 11 Evrópulöndum höfðu $80 \%$ sjúklinga, sem fengu meðferð með innöndunarsterum hér á landi, fulla stjórn á sjúkdómnum. ${ }^{5}$ Petta pýddi að einkenni voru lítil, ekkert vinnutap og engar heimsóknir á bráðamóttöku eða innlagnir. Petta var betra en hjá hinum pátttökupjóðunum.

Til að lækka lyfjakostnað hefur heilbrigðisráðherra brugðið á pað ráð að hætta niðurgreiðslu nokkurra lyfja með reglugerðarbreytingum. Petta á við um lyf við háprýstingi, hárri blóðfitu, próteinpumpuhemla og astmalyf. Astmalyfin hafa hér pá sérstöðu að öflugustu lyfin eru ekki lengur niðurgreidd, en í hinum lyfjaflokkunum er ávallt hægt að velja jafnöflug lyf og pau sem hætt er að niðurgreiða. Sækja má um lyfjaskírteini fyrir peim astmalyfjum sem hætt er að niðurgreiða og gilda pau í prjú ár.

Sjúkratryggingar Íslands hafa gefið út leiðbeiningar um meðferð á astma sem byggja á breskum leiðbeiningum (British Guidelines on the Management of Asthma. No. 101). Samkvæmt peim er astmi flokkaður í fimm stig í samræmi við meðferðarpörfina. Í rannsókn, sem ég hef áður vitnað til, skiptust 1025 astmasjúklingar pannig að 557 (54\%) notuðu ekki innöndunarstera og 116 (11\%) notuðu innöndunarstera annaðhvort óreglulega eða í litlum skömmtum. ${ }^{5}$ Petta svarar til pess að tveir af hverjum premur höfðu sjúkdóminn á stigi eitt eða á vægu formi af stigi tvö. Lyfjakostnaður peirra er innan við 150 krónur á dag, en hann fer svo stighækkandi og getur farið yfir eitt púsund krónur á dag hjá peim sem purfa á mestri meðferð að halda.

Раð er yfirlýst markmið stjórnvalda að lækka lyfjakostnað vegna astmalyfja á pessu ári um 250 milljónir króna. Stundum er á pað bent að pegar sparað er á einum stað aukist kostnaður á öðrum. Ekki parf mikla hliðrun á astma frá vægari stigum til verri einkenna pannig að kostnaður aukist vegna vinnutaps og sjúkrahúsvistar. Pegar áhrifin af aðgerðum stjórnvalda verða metin í peningum er pví markleysa að skoða lyfjakostnaðinn einan án pess að líta á aðra kostnaðarliði. Astmalyf hafa vafalaust verið bæði of- og vannotuð meðal Íslendinga, en er pá rétta svarið við pví að skerða aðgengi að öflugustu lyfjunum og auka skrifræði? Hví parf að auka tilgangslitla skriffinnsku og minnka um leið framleiðni pegar kreppir að í pjóðfélaginu? Væri ekki nær að stuðla með samstilltu átaki að betri pekkingu og um leið réttri greiningu og stigun astma og LLT pannig að peir sjúklingar sem eru vanmeðhöndlaðir í dag fengju betri meðferð og hætt væri að nota lyfin hjá peim sem ekki hafa af peim gagn?

\section{Heimildir}

1. Haahtela T, Klaukka T, Koskela K, Erhola M, Laitinen LA. Asthma programm in Finland: a community problem needs community solutions. Thorax 2001; 56: 806-14.

2. Accordini S, Corsico A, Cappa V, et al. The socio-economic cost of persistent asthma in the European Community Respiratory Helath Survey (ECRHS)II. ERS, Vienna 12/9-16/9: 2009.

3. Benediktsdóttir B, Guðmundsson G, Jörundsdóttir KB, Vollmer W, Gíslason P. Hversu algeng er langvinn lungnateppa? - Íslensk faraldsfræðirannsókn. Læknablaðið 2007; 93: 471-7.

4. Nielsen R, Johannessen A, Benediktsdóttir B, et al. Present and future costs of COPD in Iceland and Norway: results from the BOLD study. Eur Respir J 2009; 34: 850-7.

5. Cazzoletti L, Marcon A, Janson C, et al. Asthma control in Europe. A real world evaluation based on an international populationbased study. J Allergy Clin Immunol 2007; 120: 1360-7. 